\title{
Grazing resistance mechanisms in alfalfas of different aptitude in the juvenile stage
}

\author{
Simone Meredith Scheffer-Basso ${ }^{1,2}$, Andreissi Mileski Muniz $^{1}$ \\ 1 Universidade de Passo Fundo. \\ 2 Bolsista de Produtividade CNPq.
}

ABSTRACT - This study aimed at verifying whether juvenile plants of alfalfa cultivars with different aptitude (grazingtype: Alfagraze and ABT 805; hay-type: Crioula) show morphophysiological differences in order to develop a protocol for early selection for grazing persistence. Two experiments were conducted in a greenhouse, in completely randomized design and three repeplicates. In Experiment 1, plants were evaluated from successive destructive harvests at 60, 90, 120 and 150 days of age. In Experiment 2, plants at 150 days of age were cut to a 10-cm stubble and harvested at 15 and 30 days of regrowth. In Experiment 1, Alfagraze showed the lowest height $(19 \mathrm{~cm})$, internode length $(1.4 \mathrm{~cm})$ and apical bud accessibility $(15.3 \mathrm{~cm})$. Grazing-type cultivars did not differ significantly for subterranean hypocotyl diameter (3.5 mm) on the mean ages, and at 120 days of age they had lower number of leaves (56/plant) and axillary stem (2.5/plant) number as well as aerial dry matter accumulation ( $\mathrm{DM}=0.99 \mathrm{~g} / \mathrm{plant})$ in comparison to Crioula. At 150 days of age, Alfagraze had the lowest aerial dry matter accumulation (0.86 g/plant) compared to the other cultivars (1.8 g/plant). In Experiment 2, Alfagraze had higher leaf number (172/plant) compared to the mean of ABT 805 and Crioula (114/plant). The characters with the highest relative contribution for genetic divergence were number of leaves at 120 days of age (Experiment 1 ) and at 15 and 30 days of regrowth (Experiment 2) totalizing 71.5\%. The highest average Euclidean distance $(\mathrm{d}=12.3)$ was from Alfagraze to Crioula and the smallest from ABT 805 to Crioula $(\mathrm{d}=8.92)$. At the juvenile stage, it is possible to identify some grazing avoidance mechanisms in alfafa, such as the small plant height, lower apical bud accessibility and short internodes, as well as one of the grazing tolerance mechanisms, which is the increase in the number of leaves after cutting. For these characters, early selection is possible and Alfagraze can be used as witness.

Key Words: ABT 805, Alfagraze, avoidance, Crioula, tolerance

\section{Mecanismos de resistência ao pastejo em alfafas de distintas aptidões em estádio juvenil}

\begin{abstract}
RESUMO - Este estudo objetivou verificar se plantas jovens de cultivares de alfafa de distinta aptidão (tipo-pastejo: Alfagraze e ABT 805; tipo-feno: Crioula) evidenciam diferenças morfofisiológicas, a fim de desenvolver um protocolo de seleção precoce para persistência ao pastejo. Dois ensaios foram conduzidos em casa-de-vegetação, com delineamento completamente casualizado e três repetições. No Experimento 1 as plantas foram avaliadas a partir de colheitas sucessivas e destrutivas aos 60, 90, 120 e 150 dias de idade. No Experimento 2, plantas com 150 dias foram cortadas a $10 \mathrm{~cm}$ da base e avaliadas aos 15 e 30 dias de rebrota. No Experimento 1, a Alfagraze mostrou menor altura (19 cm), comprimento de entrenó $(1,4 \mathrm{~cm})$ e acessibilidade da gema apical $(15,3 \mathrm{~cm})$. As cultivares tipo-pastejo não diferiram significativamente quanto ao diâmetro do hipocótilo subterrâneo (3,5 mm), na média de idade, e aos 120 dias de idade apresentaram menor número de folhas (56/planta) e hastes axilares (2,5/planta) e acúmulo de massa seca aérea (MS = 0,99 g/planta) em relação à Crioula. Aos 150 dias de idade, a Alfagraze teve menor acúmulo de massa seca aérea (0,86 g/planta) em relação às outras cultivares (1,8 g/planta). No Experimento 2, a Alfagraze apresentou maior número de folhas (172/planta) comparado à média de ABT 805 e Crioula (114/planta). Os caracteres com maior contribuição relativa para divergência genética foram o número de folhas aos 120 dias de idade (Experimento 1), 15 e 30 dias de rebrota (Experimento 2), totalizando 71,5\%. A maior distância euclidiana média foi entre Alfagraze e Crioula $(d=12,3)$ e a menor, entre ABT 805 e Crioula $(d=8,92)$. Em estádio juvenil, é possível detectar em alfafa alguns mecanismos de evitamento ao pastejo, como pequena altura de planta, menor acessibilidade da gema apical e entrenó curto, bem como um dos mecanismos de tolerância ao pastejo, que é o aumento no número de folhas após o corte. Para estes caracteres a seleção precoce é possível e a Alfagraze pode ser utilizada como testemunha.
\end{abstract}

Palavras-chave: ABT 805, Alfagraze, Crioula, evitamento (escape), tolerância 


\section{Introduction}

Grazing resistance is an ambiguous term used to describe the moderate ability of plants to survive grazing and an additional understanding can be gained by organizing grazing resistance into tolerance and avoidance components. Avoidance mechanisms reduce the probability and severity of plant defoliation (i.e., escape mechanisms), while tolerance mechanisms facilitate growth following defoliation (i.e., mechanisms of rapid leaf replacement) (Briske, 1991).

Counce et al. (1984) verified that top growth and total nonstructural carbohydrates (TNC) in the taproots were lower for persistent alfalfa cultivars than for nonpersistent ones. Subsequent studies showed other traits for grazing persistence such as deep crown and subsuperficial and nonsynchronous budding (Smith Jr. et al., 1989). Brummer \& Bouton (1992) associated grazing tolerance with the ability of maintaining a higher residual leaf area, which would keep the total non-structural carbohydrates store maintenance, decumbent habit and a high basal bud production.

The major limiting factor in the selection for grazing tolerance in alfalfa is the difficulty to develope accurate techniques to select the many morphological and physiological traits associated with this character. Nonetheless, most of the American cultivars developed prior to 1990 were selected by broad crown and rootedness (Smith Jr. et al., 2000). Perez \& Dall'Agnol (2009) indicated that the bud density/dry matter ratio could be a descriptor of grazing aptitude in alfalfa.

Researches carried out in Brazil showed morphological variability on seedling internode length in Crioula alfalfa (Perez, 2003). This character was considered as a complementary morphological marker to select alfalfa populations more adapted to grazing. Favero et al. (2008) selected alfalfa populations with variability in dry matter yield and survival variability based in this trait. The seedling internode was shown as a predictive factor for plant height, stem number, root volume and leaf area and persistence to severe cutting in alfalfa (Favero et al., 2009).

The present study was conducted to detect grazing trait mechanisms in alfalfa cultivars with different aptitudes in order to develop a protocol for early selection of grazing persistence. This study evaluated the morphophysiological differences among hay and grazing type alfalfas in the juvenile stage in order to identify the traits related to the grazing-type and to determine the age when screening would be possible.

\section{Material and Methods}

The work was carried out in a greenhouse, in Passo Fundo, Rio Grande do Sul, Brazil, from June to December, 2001. The region climate is temperate subtropical humid (Cfa) with an average annual temperature $22^{\circ} \mathrm{C}$.

Two grazing-type alfalfas, Alfagraze (USA, semi-erect, fall dormant; Bouton et al., 1991) and ABT 805 (USA, erect, not fall dormant; Bouton et al., 1997), and a hay-type Crioula (BR, erect, not fall dormant), were evaluated in two experiments, simultaneously established. In Experiment 1, plants were evaluated in successive destructive harvests at 60, 90, 120 and 150 days of age. In Experiment 2, plants at 150 days of age were cut to a $10-\mathrm{cm}$ stubble and they were completely harvested after 15 and 30 days of regrowth. The experiments were conducted in a completely randomized design with three replications.

Plants were grown in pots containing $3 \mathrm{~kg}$ organic substrate with the following characteristics: $\mathrm{pH}_{\text {water }}=5.9$; phosphorus $=19 \mathrm{mg} / \mathrm{dm}^{3} ;$ potassium $=268 \mathrm{mg} / \mathrm{dm}^{3} ;$ aluminium $=0 \mathrm{cmol}_{\mathrm{C}} / \mathrm{dm}^{3} ;$ calcium $=8.2 \mathrm{cmol}_{\mathrm{C}} / \mathrm{dm}^{3}$ and magnesium $=5.7 \mathrm{cmol}_{c} / \mathrm{dm}^{3}$. Seeds were placed in a germinator $\left(27^{\circ} \mathrm{C}\right)$ and the vigorous seedlings were selected for growth, keeping one plant per pot. Inoculation was not performed and nitrogen fertilization (Nitrabor ${ }^{\circledR}$ ) was added every 30 days at $2.6 \mathrm{~g} / \mathrm{L}$. Two doses of Monocrotophos aqueous solution at $0.1 \%$ were necessary to control trips (Frankliniella sp.) when plants were approximately at 60 days of age. During the experimental period, the plants were kept without water restriction under automatic irrigation.

In Experiment 1, the plants were evaluated for height, crown and axillary stem number, internode length of the longest stem, apical bud accessibility (the distance from plant base to apical bud of the longest stem), leaf number and the longest root length. After the $90^{\text {th }}$ day of growth, the plants were also characterized for subterranean hypocotyl diameter and length, aerial and root dry matter (DM). In Experiment 2, all these variables were evaluated including the longest stem diameter and stem (SDM) and leaf dry matter production (LDM). From the original data it was obtained the leaf:stem ratio. The material of the two experiments was dried in an forced air oven at $60^{\circ} \mathrm{C}$ to determine dry matter.

Data were submitted for analysis of variance using the square root transformation for $\mathrm{Y}+0.5-\mathrm{SQRT}(\mathrm{Y}+0.5)$ and means were compared by Tukey's test at $5 \%$ significance, using the statistical program SISVAR (Ferreira, 2000). For both tests, the analysis of variance was performed for a factorial scheme (Experiment 1 = age $\times$ cultivar; Experiment $2=$ cultivar $\times$ regrowth day). In an effort to study the relative 
contribution of the characters on the genetic divergence among cultivars, a Singh's analysis (Singh, 1981) was performed based on the mean Euclidean distance, using the software Genes (Cruz, 2006). For this, it was used 70 out of the 78 evaluated characters that showed differences among cultivars.

\section{Results and Discussion}

Under continuous growth (Experiment 1), cultivars differed $(\mathrm{P}<0.05)$ in height, internode length, subterranean hypocotyl diameter and apical bud accessibility, regardless of age (Table 1 ). Cultivar $\times$ age interaction was not significant for these traits, indicating that cultivars were similar during 150 days of growth.

Except for hypocotyl, the growth habit was the determining factor of differences between cultivars in these attributes, in which the upright cultivars (Crioula and ABT $805)$ overcame $(\mathrm{P}<0.05)$ semi-erect Alfagraze. However, Perez \& Dall'Agnol (2009) observed a more prostrated growth habit in ABT 805 under grazing, which indicated a possible contribution of phenotypic plasticity.

Height is the best single predictor of grazing response and small size plants have avoidance mechanisms that make their frequent defoliation difficult (Diaz et al., 2001). Alfagraze showed, from 60 days of age, some avoidance mechanisms (Briske, 1991), such as smaller height, internodes, apical bud accessibility and leaf size than the upright cultivars (Figure 1). Some studies performed in Brazil showed that it is possible to select alfalfa populations with small height through the internode length at seedling stage (Favero et al., 2009), which could indirectly indicate a higher grazing persistence. Favero et al. (2008) observed higher survival for severe cut (weekly and 2-cm stubble) of a Crioula alfalfa population selected by short internode (50\% survival) in relation to that of long internode ( $25 \%$ survival).

Internode length can affect the competition among stems of the same plant or among plants. Its measure is

Table 1 - Morphological attributes of alfalfa cultivars of different aptitudes under continuous growth in the mean age (60, 90, 120 and 150 days of age)

\begin{tabular}{lcccc}
\hline Cultivar & $\begin{array}{c}\text { Height } \\
(\mathrm{cm})\end{array}$ & $\begin{array}{c}\text { Longest } \\
\text { stem } \\
\text { internode } \\
(\mathrm{cm})\end{array}$ & $\begin{array}{c}\text { Apical bud } \\
\text { accessibility } \\
(\mathrm{cm})\end{array}$ & $\begin{array}{c}\text { Subterranean } \\
\text { hypocotyl } \\
\text { diameter (mm) }\end{array}$ \\
\hline Crioula & $29.9 \mathrm{a}$ & $2.7 \mathrm{a}$ & $29.0 \mathrm{a}$ & $4.6 \mathrm{a}$ \\
ABT 805 & $32.0 \mathrm{a}$ & $2.4 \mathrm{a}$ & $30.5 \mathrm{a}$ & $3.7 \mathrm{~b}$ \\
Alfagraze & $19.0 \mathrm{~b}$ & $1.4 \mathrm{~b}$ & $15.3 \mathrm{~b}$ & $3.2 \mathrm{~b}$ \\
CV (\%) & 18.9 & 12.2 & 20.6 & 7.6 \\
\hline
\end{tabular}

Means followed by the same letter in the column do not differ by Tukey test at $5 \%$ of significance. adopted in alfalfa breeding programs with the purpose of improving the stand structure aiming to having a low initial stem elongation rate, to avoid the prevalence of some individual over others (Rotili et al., 1996). In this study, this relation was not estimated but the dominance of some stems over others was observed in ABT 805 and Crioula, what has not occurred in Alfagraze. This behavior may be associated to paradormancy, which is the bud elongation inhibition by apical bud action, and its study could help the understanding of stem dynamic and the cultivar differential response to defoliation.

Regardless of age, hay-type and grazing-type cultivars differed in subterranean hypocotyl diameter, with superiority of the Crioula cultivar (Table 1). Because this region is where the crown will be originated after getting thickened over time and this result was unexpected, Smith Jr. et al. (2000) pointed the crown as an important descriptor to select grazing-resistant alfalfa in the USA. The production of many crown buds was noted by Brummer \& Bouton (1991) in Alfagraze during the fall, which could also help its

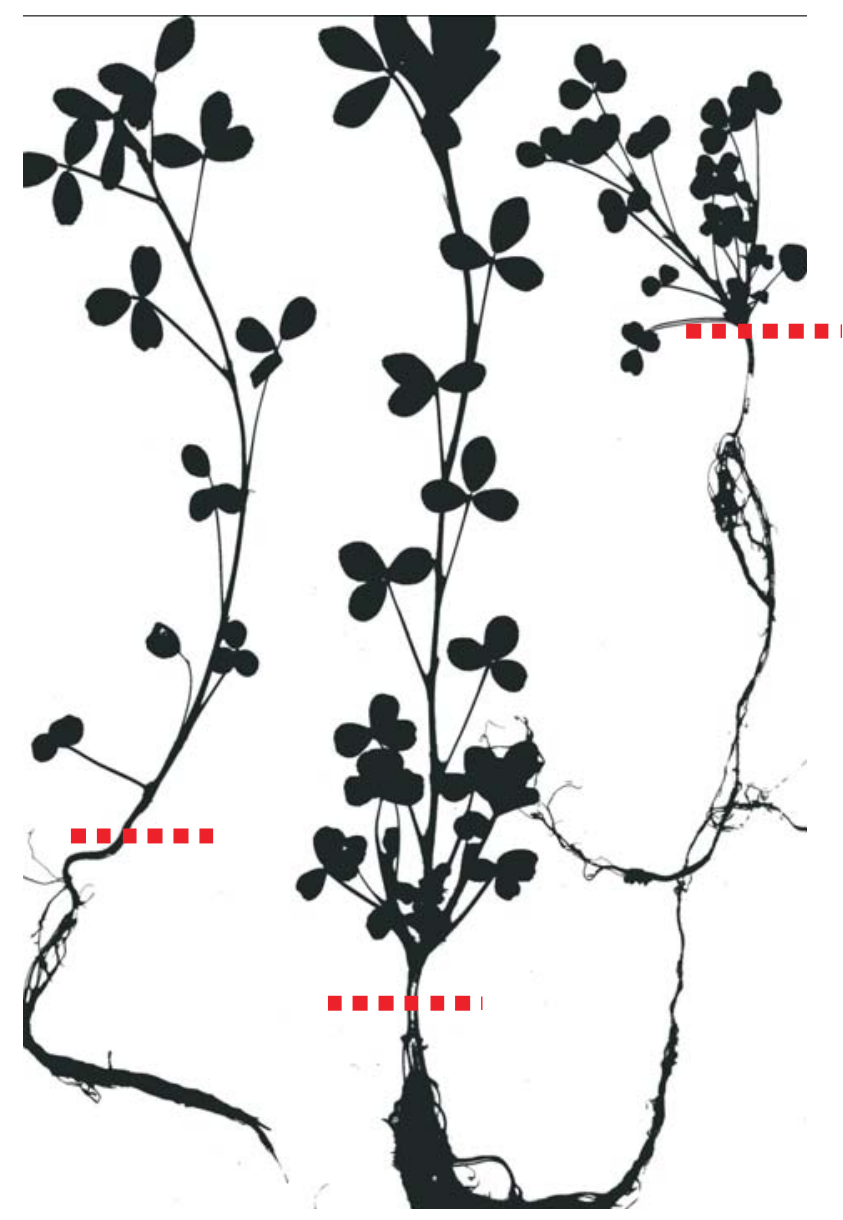

Figure 1 - Growth habit of ABT 805, Crioula and Alfagraze alfalfa cultivars at 60 days old; (...-- ) cotyledonary node. 
persistence. The divergence between these results could be explained by the differences in plant age, because in this work the crown had not been formed yet.

In Brazil, Perez \& Dall'Agnol (2009) did not verify differences on the size of the crown between ABT 805 and Crioula populations. Controversies about the importance of the crown as a determinant in grazing resistance can be associated with the fact that in some cases the crown is a variable response and in others it is a variable factor in the selection. Márquez-Ortiz et al. (1999), based on the crown trait inheritance in alfalfa, suggested that it could be possible to be successful with the selection for crown stems (number and width), but the success would be limited for the crown width and absent for bud number and crown depth.

A significant cultivar $\times$ age interaction was observed in the number of leaves (Figure 2). No differences were found until 120 days of growth, but at this age, Crioula produced 95\% more leaves compared to other cultivars, then it showed the beginning of leaf senescence. There is no evidence to indicate that grazing-type cultivars show lower leaf appearance rate and that leaf duration can be related with persistence. However, the leaf area maintenance is a decisive
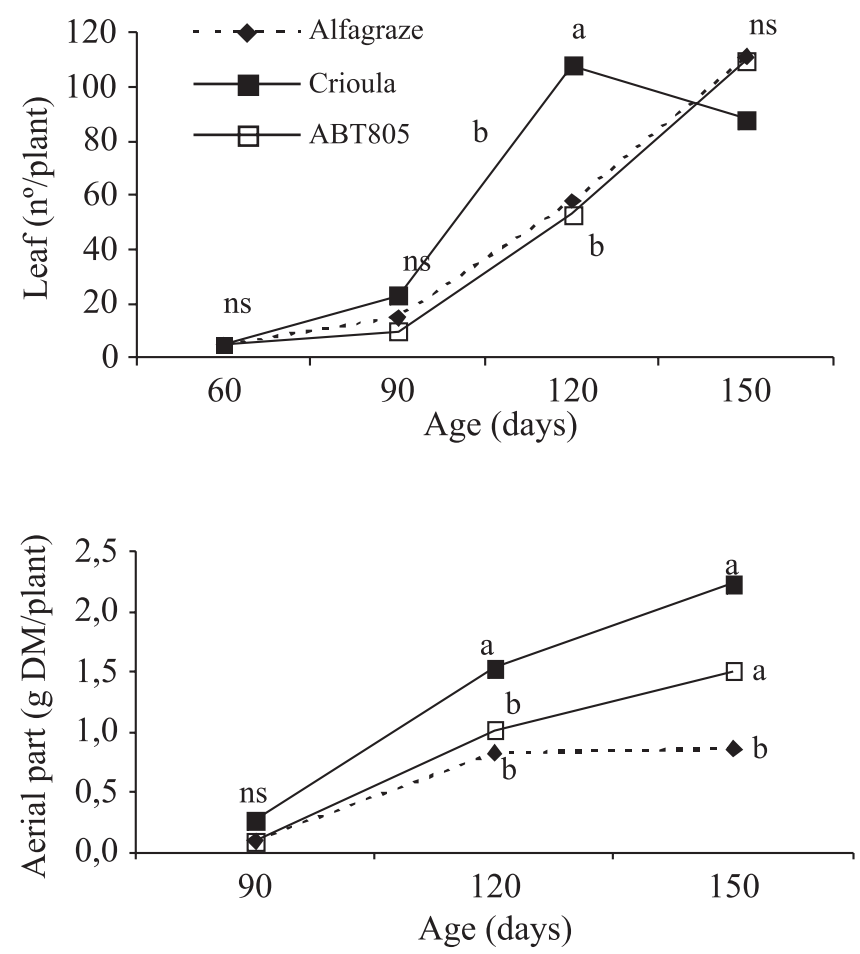

Different letters show significant difference by Tukey test $(\mathrm{P}<0.05)$ among cultivars in the same age. $\mathrm{CV}=12.6 \%$.

Figure 2 - Leaf and aerial dry matter accumulation of alfalfa cultivars considering the plant age. factor for grazing tolerance in order to keep high levels of total non-structural carbohydrates reserves (Brummer \& Bouton, 1992).

Leaf initiation and senescence synchrony maintain a relatively constant leaf number per tiller throughout most of their developmental record. Leaf demography by determining the amount of live leaf area per tiller influences both the potential photosynthetic capacity of the tiller and the amount of leaf biomass (Briske, 1991) and, consequently, forage production. The results of this work suggest that studies about leaf dynamics in alfalfa with different aptitude should be implemented. In addition to their importance in the carbon saving, leaves are determinant in the axillary bud bank and, consequently in the stem number, too. These stems are fundamental for dry matter production in alfalfa (Singh \& Winch, 1974), and the regrowth is faster when it occurs from the axillary buds.
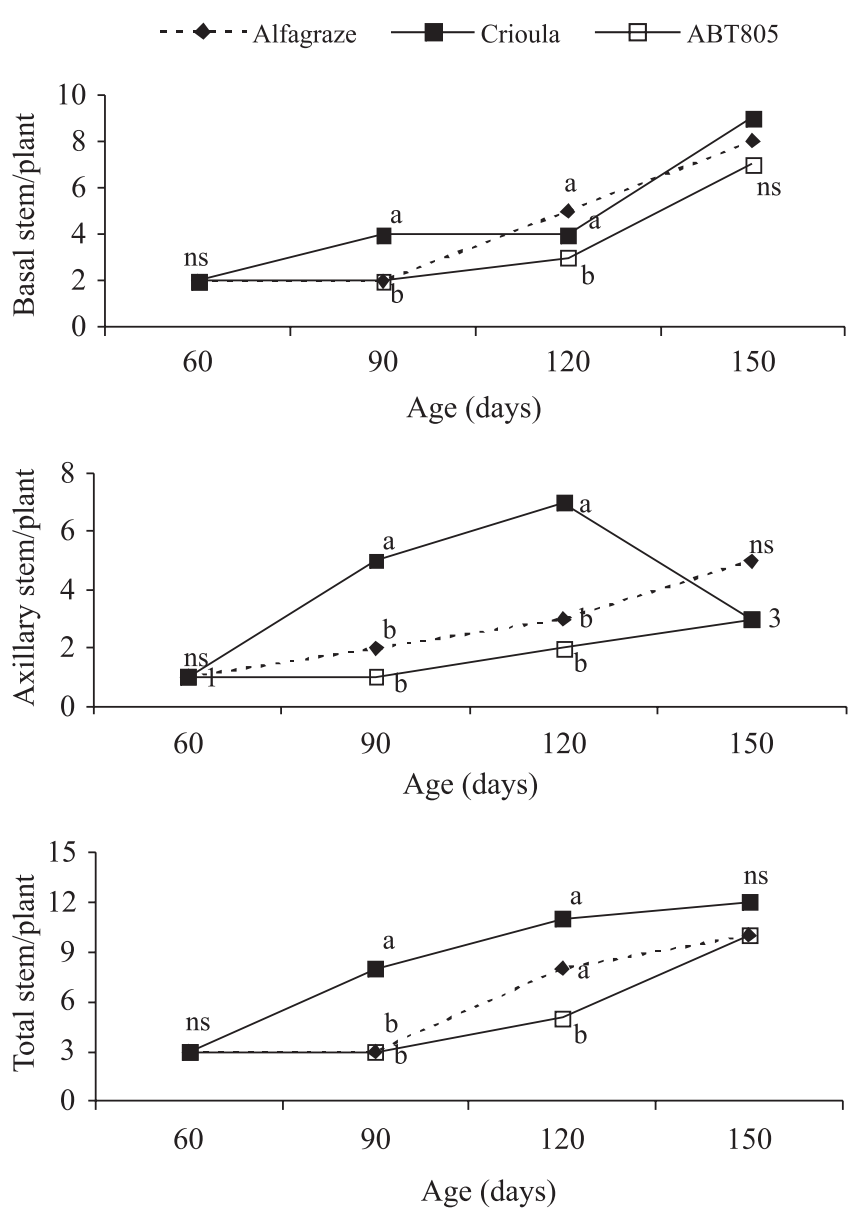

Different letters show significant difference by the Tukey's test $(\mathrm{P}<0.05)$ among cultivars in the same age. $\mathrm{CV}$ : basal stem $=10 \%$; axillary stem $=18 \%$; total stem $=12.5 \%$.

Figure 3 - Stem number of alfalfa cultivars considering the plant age.

R. Bras. Zootec., v.39, n.8, p.1684-1690, 2010 
Grazing-type cultivars did not vary over time for in the number of axillary stems ( $\mathrm{P}>0.05)$ and they were significantly inferior to Crioula at 90 and 120 days of growth (Figure 3). The biggest difference among cultivars over time was for number of basal stems. The earliest production of these stems was verified in Crioula, followed by Alfagraze and, finally, the ABT 805 , but at 150 days of growth no difference was observed. However, the significant cultivar $\times$ age interaction limits the value of this trait to early selection. Perez \& Dall'Agnol (2009) also found no difference among ABT 805, Alfagraze and Crioula in stem number. The hypothesis that grazing-type cultivars are late in leaf and stem formation deserves to be tested.

The dry matter accumulation accused effect on the cultivar $\times$ age interaction and the difference was significant only at 120 and 150 days of age (Figure 2). Crioula had the highest dry matter production at 120 days of age, surpassing ABT 805 and Alfagraze by $51 \%$ and $84 \%$, respectively. At 150 days of age, Crioula and ABT805 were similar ( $P>0.05)$, overcoming Alfagraze. This result illustrates the effect of growth habit (erect) and the highest height (Table 1) of the Crioula Cultivar, for at this age there was no variation in the stem and leaf number. The smallest dry matter accumulation of Alfagraze was a result of its reduced size, as it was for height, stem diameter, and leaf size (Figure 1). In studies evaluating plant tolerance to injuries, the important thing to consider is to compare its performance in absence and presence of this situation. The fitness difference between damaged and undamaged plants defines the tolerance (Brown \& Handley, 2006). Inthis study, after cut(Experiment2), only the leaf number was altered, with important increase of Alfagraze (Figure 4).

Comparing the values verified in the regrowth with those detected in the intact plants at the same age (150 days) in Experiment 1 (Figure 2), the increases were 180\% (Alfagraze), 55\% (ABT 805) and 31\% (Crioula), pointing out for a possible relation with their growth habit. Leaf reposition is a trait attached to grazing tolerance which depends on number, origin and local of meristem after defoliation (Briske, 1991). The most prostrate growth and the lowest height, apical bud accessibility and internode of Alfagraze explains its response, which could be the cause of its ability to keep high residual leaf area and nonstructural carbohydrates reserves, as it was pointed out by Brummer \& Bouton (1992).

The characters that most contributed for genetic divergence were the leaf number at 120 days of age (Experiment 1), 15 and 30 days of regrowth (Experiment 2), totalizing $71.5 \%$ (Table 2).
In the plants under continuous growth at 120 days of age, the hay-type cultivar was superior in relation to grazingtypes (Figure 2). After cutting, Alfagraze had the highest leaf production (Figure 4), showing a grazing tolerance mechanism.

Considering that for early selection it is essential to choose traits from the aerial part and non destructive techniques, the leaf number after cutting would be a good descriptor. This estimative is an easy, safe and precise method, which does not depend on reagents or equipments. Comparing to the bud estimative, it is really advantageous, as the visualization and counting of buds are difficult, besides not being possible to estimate its future development.

Table 2 - Relative importance (R.I) of characters affecting genetic divergence in alfalfa cultivars of different aptitude according to Singh method (1981)

\begin{tabular}{|c|c|c|c|}
\hline Character & RI (\%) & Character & RI (\%) \\
\hline ABA-20 & 4.4500 & AXS-120 & 0.1488 \\
\hline ABA-15 & 0.6020 & AXS-15 & 0.1008 \\
\hline ABA-150 & 2.3400 & AXS-150 & 0.0292 \\
\hline ABA-30 & 1.4700 & AXS-30 & 0.0024 \\
\hline ABA-60 & 0.0892 & AXS-90 & 0.1080 \\
\hline ABA-90 & 1.3300 & BS-15 & 0.0348 \\
\hline H-120 & 2.9437 & BS-30 & 0.0219 \\
\hline H-15 & 1.0400 & BS-90 & 0.0201 \\
\hline H-150 & 2.0250 & TS-120 & 0.2197 \\
\hline $\mathrm{H}-30$ & 1.2200 & TS-15 & 0.0219 \\
\hline $\mathrm{H}-60$ & 0.1171 & TS-150 & 0.0511 \\
\hline $\mathrm{H}-90$ & 0.7588 & TS-30 & 0.0388 \\
\hline IL-120 & 0.0118 & TS-90 & 0.2212 \\
\hline IL-15 & 0.0016 & LDM-15 & 0.0002 \\
\hline IL-150 & 0.0213 & LDM-30 & 0.0008 \\
\hline IL-30 & 0.0016 & SDM-15 & 0.0002 \\
\hline IL-60 & 0.0036 & SDM-30 & 0.0228 \\
\hline IL-90 & 0.0124 & APDM-120 & 0.0128 \\
\hline SHL-15 & 0.0012 & APDM-15 & 0.0010 \\
\hline SHL-30 & 0.0025 & APDM-150 & 0.0032 \\
\hline RL-120 & 0.4880 & APDM-30 & 0.0005 \\
\hline RL-15 & 0.2337 & APDM-90 & 0.0002 \\
\hline RL-150 & 3.3959 & RDM-120 & 0.0058 \\
\hline RL-30 & 0.0057 & RDM-15 & 0.0012 \\
\hline RL-60 & 0.0254 & RDM-150 & 0.0010 \\
\hline RL-90 & 0.4832 & RDM-90 & 0.0001 \\
\hline SHD-15 & 0.0074 & TDM-120 & 0.0310 \\
\hline SHD-30 & 0.0008 & TDM-15 & 0.0041 \\
\hline DBS-15 & 0.0021 & TDM-150 & 0.0086 \\
\hline DBS-30 & 0.0057 & TDM-30 & 0.0010 \\
\hline LN-120 & 20.6373 & TDM-90 & 0.0004 \\
\hline LN-15 & 25.0278 & LSR-15 & 0.0001 \\
\hline LN-150 & 3.7034 & LSR-30 & 0.0002 \\
\hline LN-30 & 25.4939 & RPA15 & 0.0001 \\
\hline$\underline{\mathrm{LN}-90}$ & 0.8984 & RPA30 & 0.0001 \\
\hline \multicolumn{4}{|c|}{$\begin{array}{l}\text { ABA = apical bud accessibility; } \mathrm{H}=\text { height; } \mathrm{IL}=\text { internode length; } \\
\mathrm{SHL}=\text { subterranean hypocotyl length; } \mathrm{RL}=\text { length of the longest root; } \\
\text { SHD = subterranean hypocotyl diameter; DBS = diameter of the longest stem } \\
\text { diameter; LN = leaf number; AXS = axillary stem; BS = basal stem; TS = total } \\
\text { stems; LDM = leaf dry matter; SDM = stem dry matter; APDM = aerial part dry } \\
\text { matter; RDM = root dry matter; TDM = total dry matter; LSR = LDM:SDM; } \\
\text { RAP = RDM:APDM. The numbers } 15 \text { and } 30 \text { show the days after cutting } \\
\text { (Experiment 2) and 60, 90, } 120 \text { and } 150 \text { the plant age (Experiment } 1 \text { ). }\end{array}$} \\
\hline
\end{tabular}

R. Bras. Zootec., v.39, n.8, p.1684-1690, 2010 


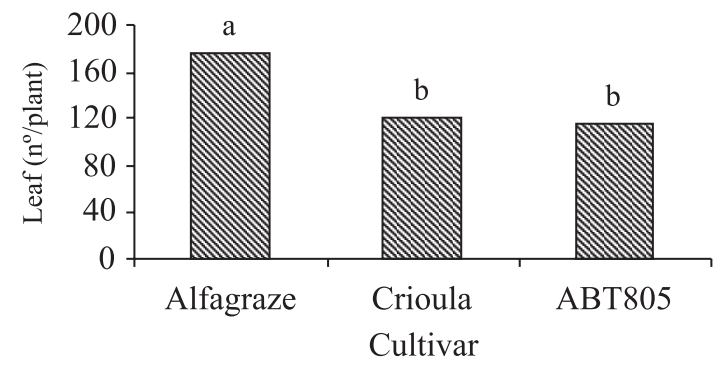

Different letters show significant difference by the Tukey test $(\mathrm{P}<0.05)$ among cultivars. $\mathrm{CV}=11.1 \%$.

Figure 4 - Leaf number of alfalfa cultivars after cut considering the average of 15 and 30 regrowth day.

However, the leaf number in the regrowth does not solely define the grazing aptitude, because the results indicated similarity $(\mathrm{P}>0.05)$ between the cultivars with different aptitude, ABT 805 (grazing-type) and Crioula (hay-type). This result is attributed to growth habit (erect). The mean Euclidean distance confirmed the growth habit effect on the performance and relationship among cultivars. The smallest distance was detected between ABT 805 and Crioula ( $\mathrm{d}=8.92)$ and the biggest was between Alfagraze and Crioula (d=12.3). Alfagraze and ABT 805 had intermediary distance $(\mathrm{d}=11.9)$.

The present data indicate that both grazing-types have differences as for grazing resistance mechanisms, possibly related to physiological aspects, such as photosynthetic efficiency and NSC reserves, not studied here. Ferragine et al. (2004), in São Paulo, showed bigger survival in Alfagraze (25.9\%) comparing to ABT 805 (10.7\%) when grazed, enhancing this hypothesis. The authors pointed similarities between the productions of ABT 805 (17,600 kg DM/ha/year) and Crioula (18,300 kg DM/ha/year), significantly higher than Alfagraze (13,300 kg DM/ha), with rotated stocking rate. Under continuous stocking, Crioula was inferior (19,900 kg DM/ha/year) to the grazing-type cultivars $($ ABT $805=26,600 \mathrm{~kg}$ DM/ha/year; Alfagraze = 26,300 kg DM/ha/year). Under cutting, Saibro et al. (2001) reported increased production of Crioula $(8,618 \mathrm{~kg} \mathrm{DM} / \mathrm{ha} /$ year) in relation to Alfagraze (5,826 kg DM/ha/year), but with the same stand survival (65\%).

\section{Conclusions}

Regardless of growth habit, grazing-type cultivars (Alfagraze, semi-erect; ABT 805, erect) differ from hay-type (Crioula) for hypocotyl subterranean diameter and basal stems (90 days old) as well as in the number of leaves, basal and axillary stem (120 days old), with superiority for Crioula.

In young plants, it is possible to identify grazing avoidance mechanisms, such as the small plant height, lower apical bud accessibility and short internodes, as well as a grazing tolerance mechanism, which is the increase of leaf number in the regrowth period. It is possible to use these traits for early selection and Alfagraze can be used as a control for the screening procedure.

\section{References}

BOUTON, J.H.; SMITH JR., S.R.; WOOD, D.T. et al. Registration of 'Alfagraze' alfalfa. Crop Science, v.31, p.479, 1991.

BOUTON, J.H.; GATES, R.N.; WOOD, D.T. Registration of 'ABT 805' alfalfa. Crop Science, v.37, p.293, 1997.

BRISKE, D.D. Developmental morphology and physiology of grasses. In: HEITSCHMIDT, R.K.; STUTH, J.W. (Eds.). Grazing management: an ecological perspective. Portland: Timber Press, 1991. p.85-108.

BROWN, J.K.M.; HANDLEY, R.J. Fight or flinch? Heredity, v.96, p.3-4, 2006.

BRUMMER, E.C.; BOUTON, J.H. Plant traits associated with grazingtolerant alfalfa. Agronomy Journal, v.83, p.996-1000, 1991.

BRUMMER, E.C.; BOUTON, J.H. Plant traits associated with grazing-tolerant alfalfa. Agronomy Journal, v.84, p.138-143, 1992.

COUNCE, P.A.; BOUTON, J.H.; BROWN, R.H. Screening and characterizing alfalfa for persistence under mowing and continuous grazing. Crop Science, v.24, p.282-285, 1984.

CRUZ, C.D. Programa Genes: Análise multivariada e simulação. Viçosa, MG: Editora UFV, 2006. 175p.

DÍAZ, S.; NOY-MEIR, I.; CABIDO, M. Can grazing response of herbaceous plants predicted from simple vegetative traits? Journal of Applied Ecology, v.38, p.497-508, 2001.

FAVERO, D.; SCHEFFER-BASSO, S.M.; DALL'AGNOL, M. et al. Desempenho de populações de alfafa sob distintos níveis de desfolhação. Revista Brasileira de Zootecnia, v.37, n.4, p.589-595, 2008.

FAVERO, D.; SCHEFFER-BASSO, S.M.; CARNEIRO, C.M. Morphological development of Alfagraze cultivar and Crioula alfalfa populations selected at the seedling stage. Revista Brasileira de Zootecnia, v.38, n.4, p.605-610. 2009.

FERRAGINE, M. de. C.; PEDREIRA, C.G.S.; OTANI, L. et al. Produção estacional, índice de área foliar e interceptação luminosa de cultivares de alfafa sob pastejo. Pesquisa Agropecuária Brasileira, v.39, p.1041-1048, 2004.

FERREIRA, D.F. Análises estatísticas por meio do Sisvar para Windows versão 4.0. In: REUNIÃO ANUAL DA REGIÃO BRASILEIRA DA SOCIEDADE INTERNACIONAL DE BIOMETRIA, 45., 2000. São Carlos. Anais... São Carlos: UFSCAR, 2000. p.255-258.

MÁRQUEZ-ORTIZ, J.J.; LAMB, J.F.S.; JOHNSON, L.D. et al. Heritability of crown traits in alfalfa. Crop Science, v.39, p.38-43. 1999.

PEREZ, N.B. Melhoramento genético de leguminosas de clima temperado - alfafa (Medicago sativa L.) e cornichão (Lotus corniculatus L.) para aptidão ao pastejo. 2003. Tese (Doutorado em Zootecnia) - Faculdade de Agronomia/ Universidade Federal do Rio Grande do Sul, Porto Alegre.

PEREZ, N.B.; DALL'AGNOL, M. Características morfológicas de plantas de alfafa relacionadas à aptidão ao pastejo. Revista Brasileira de Zootecnia, v.38, n.3, p.418-421, 2009.

ROTILI, P.; BERARDO, N.; GNOCCHI, G. et al. Research activity on Medicago spp. as Instituto Sperimentale per La Colture Foraggere 
Lodi-Italy. CIHEAM-IAMZ, v.18, p.11-22. 1996. Disponível em: $<$ http://ressources.ciheam.org> Acesso em: 9/8/2009.

SAIBRO, J.C.; BATTISTI, R.; FREITAS, T.M.S. Agronomic evaluation of alfalfa cultivars in Rio Grande do Sul, Brazil. In: INTERNATIONAL GRASSLAND CONGRESS, 9., 2001, São Pedro. Proceedings... Piracicaba: Fundação de Estudos Agrários Luiz de Queiroz, 2001. p.533-533.

SINGH, D. The relative importance of traits affecting genetic divergence. The Indian Journal of Genetic and Plant Breeding, v.41, p.237-245, 1981.
SINGH, Y.; WINCH, J.E. Morphological development of two alfalfa cultivars under various harvesting schedules. Canadian Journal of Plant Science, v.54, p.79-87, 1974.

SMITH JR., S.R.; BOUTON, J.H.; HOVELAND, C.S. Alfalfa persistence and regrowth potential under continuous grazing. Agronomy Journal, v.81, p.960-965, 1989.

SMITH JR., S.R.; BOUTON, J.H.; SINGH, A. et al. Development and evaluation of grazing-tolerant alfalfa cultivars: a review. Canadian Journal of Plant Science, v.80, p.503-512, 2000. 